\title{
Saturated non-esterified fatty acids stimulate de novo diacylglycerol synthesis and protein kinase $c$ activity in cultured aortic smooth muscle cells
}

\author{
H. Y. Yu, T. Inoguchi, M. Kakimoto, N. Nakashima, M. Imamura, T. Hashimoto, F. Umeda, H. Nawata \\ Graduate School of Medical Sciences, Kyushyu University, Fukuoka, Japan
}

\section{Abstract}

Aims/hypothesis. Insulin resistance is linked with a cluster of multiple risk factors and excessive acceleration of atherosclerosis. The underlying mechanism is not, however, fully understood.

Methods. To determine the link between insulin resistance and altered vascular function, we focused on the effect of various non-esterified fatty acids on diacylglycerol-protein kinase $\mathrm{C}$ pathway and mitogenactivated protein kinase activity in cultured aortic smooth muscle cells.

Results. Incubation of the cells with saturated non-esterified fatty acids $(200 \mu \mathrm{mol} / \mathrm{l})$ for $24 \mathrm{~h}$, such as palmitate or stearate, induced a significant increase in diacylglycerol concentrations by about fivefold or eightfold, respectively, whereas oleate induced a slight increase in diacylglycerol concentrations by 1.8-fold and arachidonate induced none. In addition, the increased diacylglycerol concentrations induced by palmitate were completely restored to control concentrations by triacsin $\mathrm{C}$, acyl-CoA synthetase inhibitor. These results suggest that saturated non-esterified fatty acids may increase diacylglycerol con- centrations through de novo pathway by stepwise acylation. In parallel with the increased diacylglycerol, incubation of the cells with saturated non-esterified fatty acids significantly induced the activation of protein kinase $\mathrm{C}$ and mitogen-activated protein kinase. The palmitate-induced increase in mitogen-activated protein kinase activity was restored to control concentrations by GF109203X $\left(5 \cdot 10^{-7} \mathrm{~mol} / \mathrm{l}\right)$, a specific protein kinase $\mathrm{C}$ inhibitor, suggesting a protein kinase $\mathrm{C}$-dependent activation of mitogen-activated protein kinase.

Conclusion/interpretation. Saturated non-esterified fatty acids induced an increase in de novo diacylglycerol synthesis and subsequent activation of protein kinase $\mathrm{C}$ and mitogen-activated protein kinase in cultured aortic smooth muscle cells. This could contribute to the altered vascular functions in the insulin resistant state. [Diabetologia (2001) 44: 614-620]

Keywords Non-esterified fatty acids, diacylglycerol, protein kinase $\mathrm{C}$, mitogen-activated protein kinase, insulin resistance, aortic smooth muscle cell
Received: 29 September 2000 and in revised form: 11 January 2001

Corresponding author: Toyoshi Inoguchi, M.D., Department of Medicine and Bioregulatory Science, Graduate School of Medical Sciences, Kyushyu University, Fukuoka 812-8582, Japan

Abbreviations: DAG, diacylglycerol; PKC, protein kinase C; NEFA, non-esterified fatty acids; MAP, mitogen-activated protein; SMC, smooth muscle cells.
Insulin resistance is linked with a cluster of multiple risk factors for atherosclerosis, such as diabetes, hypertension and dyslipidaemia. The underlying mechanism for a cluster of risk factors and subsequent acceleration of atherosclerosis, however, are not fully understood. Recently, non-esterified fatty acids (NEFAs) have emerged as an important link between obesity, insulin resistance, and Type II (non-insulindependent) diabetes mellitus [1]. Plasma non-esterified fatty acids (NEFAs), which are commonly higher in obesity, can induce peripheral and hepatic insulin 
resistance [2]. Furthermore, it has been hypothesized that a chronic increase of plasma NEFAs induces the impairment of beta cells and ultimately results in Type II diabetes [3-5], although this hypothesis is still controversial. In contrast, acute increase of plasma NEFAs stimulate glucose-induced insulin secretion [6-9]. These findings suggest that NEFAs serve not only as an important energy source for most body tissues particularly during periods of food deprivation but also as potent signalling entities in a variety of cellular processes. It should be noted that raising plasma NEFAs can increase vascular resistance and blood pressure (10). Several studies have also shown that plasma NEFAs in obese hypertensives are highly resistant to suppression by insulin and correlate with blood pressure [11-12]. Thus, a great deal of evidence points to the possibility that an increase of plasma NEFAs might be associated with increased tendency of hypertension and excessive acceleration of atherosclerosis in obesity or insulin resistant state. Little is known, however, about the molecular mechanism for the effects of NEFAs on vascular cells.

In the diabetic state, we and other investigators have shown that high glucose concentrations stimulate diacylglycerol (DAG)-protein kinase C (PKC) pathway in both macrovascular and microvascular tissues [13-17], which are supposed to alter a variety of vascular functions [18-26]. Thus, PKC activation in vascular tissues induced by high glucose concentrations could contribute to the excessive acceleration of atherosclerosis as well as the onset or development of microangiopathy in diabetic patients or both. The increase in DAG concentrations induced by high glucose concentrations has been supposed to be mainly derived from the de novo synthesis pathway [14-16]. We speculated that increases of plasma NEFAs as well as increased glucose concentrations might stimulate DAG synthesis in vascular cells, because excessive influx of NEFAs into vascular cells could lead to increases in acyl-CoA concentrations and then increase DAG concentrations through the de novo pathway by stepwise acylation. Hence, increases of plasma NEFAs might activate DAG- PKC pathway in vascular cells and subsequently contribute to an increase tendency to hypertension and an excessive acceleration of atherosclerosis in patients with the insulin resistance syndrome.

In this study, we examined the effect of various NEFAs on DAG-PKC pathway in cultured aortic smooth muscle cells. Activation of PKC is involved in cell growth, proliferation and contraction [27-29]. In addition, we therefore examined the effect of NEFAs on the activity of mitogen-activated protein (MAP) kinase which is a key signalling enzyme of the mitogenic process [30-32]. These might contribute to understanding the mechanism linking insulin resistance, the cluster of multiple risk factors and subsequent excessive acceleration of atherosclerosis.

\section{Methods and materials}

Cell culture. Bovine aortic smooth muscle cells were obtained from calf aorta as described [14, 15]. The cells were cultured with Dulbecco's modified Eagle' s medium (DMEM) containing $10 \%$ fetal calf serum and $100 \mathrm{mU} / \mathrm{ml}$ penicillin and $100 \mathrm{mg} /$ $\mathrm{ml}$ streptomycin at $37^{\circ} \mathrm{C}$ under atmosphere of $95 \% \mathrm{O}_{2} / 5 \%$ $\mathrm{CO}_{2}$. Every 5 to 10 days, the cells were subcultured by $0.05 \%$ trypsin harvesting.

Solubilization of fatty acids. Non-esterified fatty acids (NEFAs), including palmitate, stearate, oleate and arachidonate were purchased from Sigma Chemical (St. Louis, Mo., USA). A stock solution of NEFAs was prepared by dissolving them in $0.1 \mathrm{~N} \mathrm{NaOH}$ solution in a bath of boiling water. Appropriate volumes of these stock solutions, freshly prepared before each experiment, were then added slowly and during continuous agitation to the medium with NEFA-free BSA $(100 \mu \mathrm{mol} / \mathrm{l})$. Most NEFA molecules are bound to BSA in the solution [33]. Therefore, in this study, the fixed concentration of NEFA-free BSA was used and the absolute concentrations of NEFAs used were varied to obtain the desired concentration of freeNEFAs.

Extraction and assay of $D A G$. For the experiments, cells were allowed to reach confluence in $60 \mathrm{~mm}$ dishes, and then the medium was changed to DMEM supplemented with various concentrations of NEFAs, $100 \mu \mathrm{mol} / \mathrm{l} \mathrm{BSA}$ and no serum. At the end of the desired exposure time, the experiment was terminated by adding ice-cold methanol. Samples were harvested and transferred to chloroform-resistant tubes. After addition of $2 \mathrm{ml}$ chloroform and $1 \mathrm{ml} \mathrm{H}_{2} \mathrm{O}$ to the samples, total lipids were extracted according to the methods described previously [34]. Total DAG was measured by an enzymatic assay kit using DAG kinase (Amersham, Arlington Heights, Ill., USA), as reported previously [14-16]. Briefly, the resulting ${ }^{32} \mathrm{P}$-phosphatidic acid which was converted from DAG by DAG kinase in vitro was separated on silica gel $G$ thin layer plates, developed in chambers using a solvent of chloroform-acetone-methanolacetic acid-water (10:4:3:1). The spots of phosphatidic acid visualized by autoradiography were scraped from the plates into vials and radioactivity was measured by liquid scintillation counting.

$P K C$ assay. The PKC activity was measured by in situ PKC assay in digitonin-permeabilized cultured smooth muscle cells as reported previously [35]. For the assay, the cells were cultured on 12-well flat bottomed microtitre plates. After confluence, the medium was changed to DMEM containing various concentrations of NEFAs, PMA $\left(5 \cdot 10^{-7} \mathrm{~mol} / \mathrm{l}\right)$ (Sigma, St. Louis, Mo., USA) or GF109203X $\left(5 \cdot 10^{-7} \mathrm{~mol} / \mathrm{l}\right)$ (Sigma, St. Louis, Mo., USA), a specific PKC inhibitor, with $100 \mu \mathrm{mol} / \mathrm{l} \mathrm{BSA}$ and no serum. At the end of the desired exposure time, the medium was aspirated and replaced with a buffered salt solution containing $137 \mathrm{mmol} / \mathrm{l} \mathrm{NaCl}, 5.4 \mathrm{mmol} / \mathrm{l} \mathrm{KCl}, 10 \mathrm{mmol} / \mathrm{l}$ $\mathrm{MgCl}_{2}, 0.3 \mathrm{mmol} / \mathrm{l}$ sodium phosphate, $0.4 \mathrm{mmol} / \mathrm{l}$ potassium phosphate, $25 \mathrm{mmol} / \mathrm{l}$ beta-glycerophosphate, $5.5 \mathrm{mmol} / \mathrm{l}$ D-glucose, $5 \mathrm{mmol} / \mathrm{l}$ EGTA, $1 \mathrm{mmol} / 1 \mathrm{CaCl}_{2}, 100 \mu \mathrm{mol} / \mathrm{l} \gamma^{32} \mathrm{P}$ ATP (Amersham acid), $50 \mu \mathrm{g} / \mathrm{ml}$ digitonin, and $20 \mathrm{mmol} / \mathrm{l}$ hydroxyethylpiperazine-ethanesulphonic acid (HEPES) $(\mathrm{pH}$ $7.2,30^{\circ} \mathrm{C}$ ). In addition, a $100 \mu \mathrm{mol} / 1 \mathrm{PKC}$-specific octapeptide substrate (VRKRLRRL) was added to the buffer. The kinase reaction proceeded for $10 \mathrm{~min}$ at $30^{\circ} \mathrm{C}$ before termination by the addition of $10 \mu \mathrm{l}$ of $25 \%$ (wt/vol) TCA. Aliquot (45 $\mu \mathrm{l})$ of the reaction mixture was spotted onto $2-\mathrm{cm}$ phosphocellulose filter (Whatman P-81) and the filter was washed with $75 \mathrm{mmol} / \mathrm{l}$ phosphoric acid three times. The PKC-dependent 
phosphorylation of the peptide substrate bound to the filter was quantified by scintillation counting.

MAP kinase assay. For the assay of MAP kinase, the cells were cultured on $35 \mathrm{~mm}$ dishes. The cells were scraped and then homogenized on ice with 20 strokes of a Dounce homogenizer in a buffer containing $10 \mathrm{mmol} / \mathrm{l}$ TRIS, $150 \mathrm{mmol} / \mathrm{l} \mathrm{NaCl}$, $2 \mathrm{mmol} / \mathrm{l}$ EGTA, $2 \mathrm{mmol} / \mathrm{l}$ DTT, $1 \mathrm{mmol} / \mathrm{l}$ orthovanadate, $1 \mathrm{mmol} / \mathrm{l}$ phenylmethylsulfonyl fluoride, $10 \mu \mathrm{g} / \mathrm{ml}$ leupeptin, $10 \mu \mathrm{g} / \mathrm{ml}$ aprotinin, $\mathrm{pH}$ 7.4. The homogenates were centrifuged at $10000 \mathrm{~g} \cdot 20 \mathrm{~min}$ to precipitate cell debris. Immediately, the MAP kinase activity was measured with p42/p44 MAP kinase enzyme assay kit purchased from Amersham (Arlington Heights, Ill., USA). For western blot analysis, the samples were denatured by boiling in Laemmli sample buffer, subjected to SDS-PAGE, and immunoblotted with phospho-specific MAP kinase antibody (New England Biolabs, Beverly, Mass., USA). The blots were then incubated with horseradish peroxidase-linked second antibody followed by chemiluminescence detection, according to the manufacture's instructions (Pierce, Rockford, Ill., USA). And then, the blots were stripped and reblotted with anti-Erk-1 antibody (Santa Cruz Biotechnology, Santa Cruz, Calif., USA).

Statistical analysis. Statistical analysis was done by analysis of variance (ANOVA) followed by Fisher's comparison test.

\section{Results}

Palmitate stimulated DAG concentrations in a timedependent (0, 1, 3, 6, 12, and $24 \mathrm{~h})$ (Fig. 1A) and a concentration-dependent $(0,25,50,100$, and $200 \mu \mathrm{mol} / \mathrm{l}$ ) manner (Fig. 1B) in cultured aortic smooth muscle cells. The palmitate-stimulated DAG concentration reached the peak at $24 \mathrm{~h}$ and was sustained at least until $72 \mathrm{~h}$ (data not shown). Incubation with the physiological concentration $(200 \mu \mathrm{mol} / \mathrm{l})$ of palmitate for $24 \mathrm{~h}$ significantly increased DAG concentrations in cultured aortic smooth muscle cells by $488 \%(p<0.01)$ (Fig. 2). Incubation with stearate $(200 \mu \mathrm{mol} / \mathrm{l})$ for $24 \mathrm{~h}$ also induced a significant increase in DAG concentrations by $807 \%(p<0.01)$, whereas incubation with oleate $(200 \mu \mathrm{mol} / \mathrm{l})$ induced a small, but significant increase in DAG concentrations by $176 \%(p<0.05)$ and incubation with arachidonate $(200 \mu \mathrm{mol} / \mathrm{l})$ did not significantly change DAG concentrations (Fig. 2). To identify the source of the increased DAG concentrations induced by saturated NEFA, the effect of triacsin C (Biomol, Pa., USA), acyl-CoA synthetase inhibitor, was examined. Triacsin C $(5 \mu \mathrm{mol} / \mathrm{l})$ completely restored the increased DAG concentrations induced by palmitate to control concentrations (Fig. 3), clearly suggesting that palmitate increases the DAG concentrations through de novo pathway.

To confirm the specificity of the PKC assay, we first examined the effect of PMA, a PKC stimulator, and GF109203X, a PKC specific inhibitor, on the PKC activity in cultured aortic smooth muscle cells. Exposing the cells to PMA $\left(5 \cdot 10^{-7} \mathrm{~mol} / \mathrm{l}\right)$ for $2 \mathrm{~h}$ in-
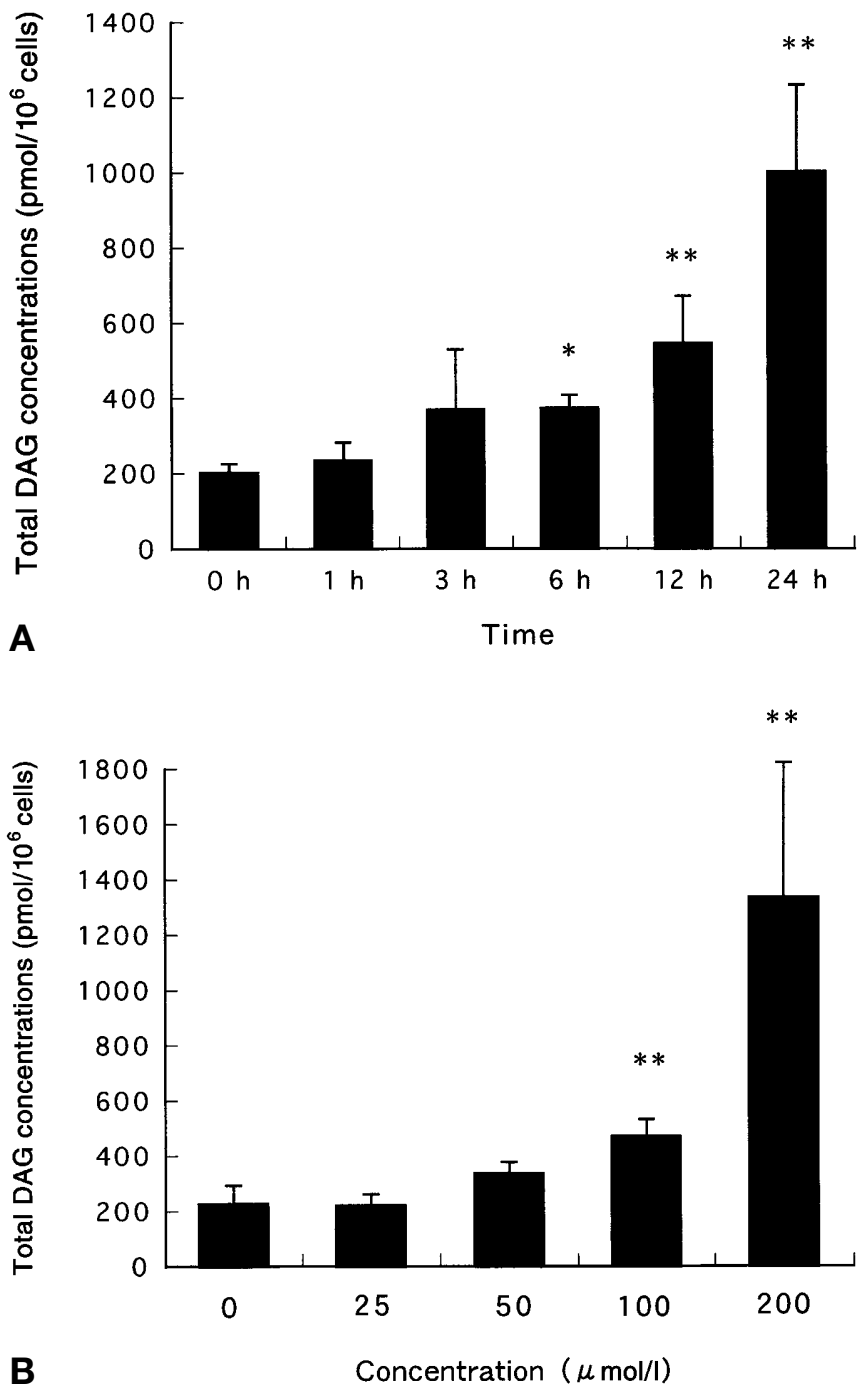

Fig.1(A, B). (A) Time-dependent increase in DAG concentrations in response to palmitate. (B) Concentration-dependent increase in DAG concentrations in response to palmitate. Confluent cultured aortic smooth muscle cells were exposed to palmitate $(200 \mu \mathrm{mol} / \mathrm{l})$. After various indicated intervals, total DAG concentrations was measured. Both results were from 1 experiment with 3 dishes per group. Both results were confirmed by 3 separate independent experiments. Results were expressed as mean values \pm SEM normalized by cell number. $* p<0.05,{ }^{*} p<0.01$ vs basal value of DAG concentrations

duced a significant increase in PKC activity by $186 \% \quad(p<0.001)$ and exposing the cells to GF109203X $\left(5 \cdot 10^{-7} \mathrm{~mol} / \mathrm{l}\right)$ for $2 \mathrm{~h}$ induced a significant decrease in PKC activity by $59 \%(p<0.001)$, (Fig.4). Next, incubation with both palmitate and stearate stimulated PKC activity by $136 \%$ and by $142 \%(p<0.05, p<0.05$, respectively).

Palmitate $(200 \mu \mathrm{mol} / \mathrm{l})$ stimulated MAP kinase activity in a time-dependent $(0,6,12,24)$ manner in parallel with DAG changes (Fig.5). Incubation with both palmitate $(200 \mu \mathrm{mol} / \mathrm{l})$ and stearate $(200 \mu \mathrm{mol} / \mathrm{l})$ for $24 \mathrm{~h}$ induced the significant increase in MAP kinase activity (Fig.6). Western blot analysis using 


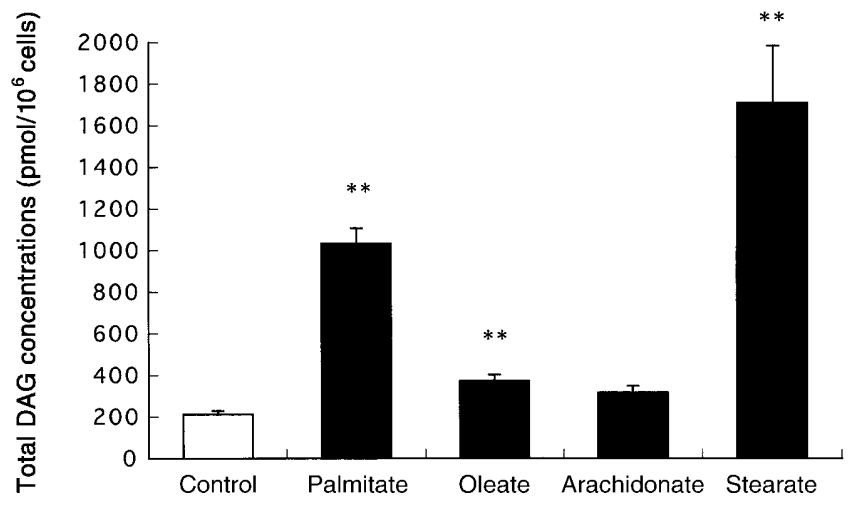

Fig. 2. Effect of various non-esterified fatty acids on total DAG concentrations. Confluent cultured aortic smooth muscle cells were exposed to various non-esterified fatty acids $(200 \mu \mathrm{mol} / \mathrm{l})$. After $24 \mathrm{~h}$ incubation, total DAG concentrations were measured. Results were expressed as means \pm SEM normalized by cell number. ${ }^{* *} p<0.01$ vs control value

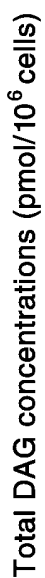

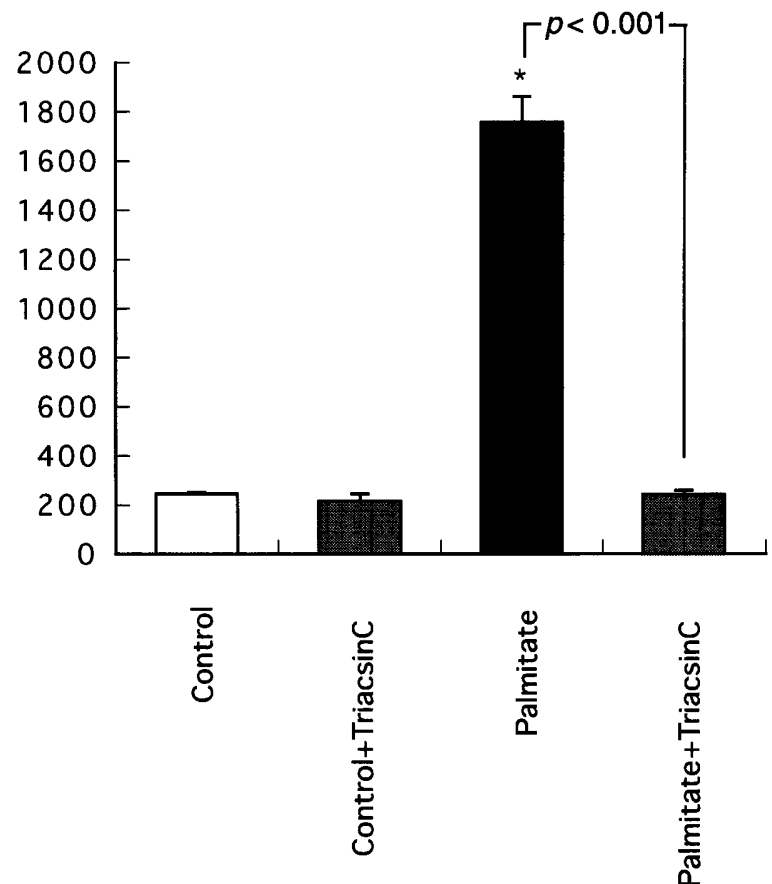

Fig. 3. Effect of Triacsin C on the increase in DAG concentrations induced by palmitate. Confluent cultured aortic smooth muscle cells were exposed to control media with or without Triacsin C, or control media containing palmitate $(200 \mu \mathrm{mol} / \mathrm{l})$ with or without triacsin C. After $24 \mathrm{~h}$ incubation, total DAG concentrations were measured. Results were expressed as means \pm SE normalized by cell number. $* * p<0.01$ vs control value

phospho-specific MAP kinase antibody also showed the palmitate-induced phosphorylation of both $\mathrm{p} 42$ and p44 MAP kinase (Fig. 7). Expression of MAP kinase, as assessed by western blotting with a polyclonal anti-Erk-1 antibody, showed that protein concentrations were not altered by palmitate (Fig. 7). To confirm that PKC has a role in the activation of

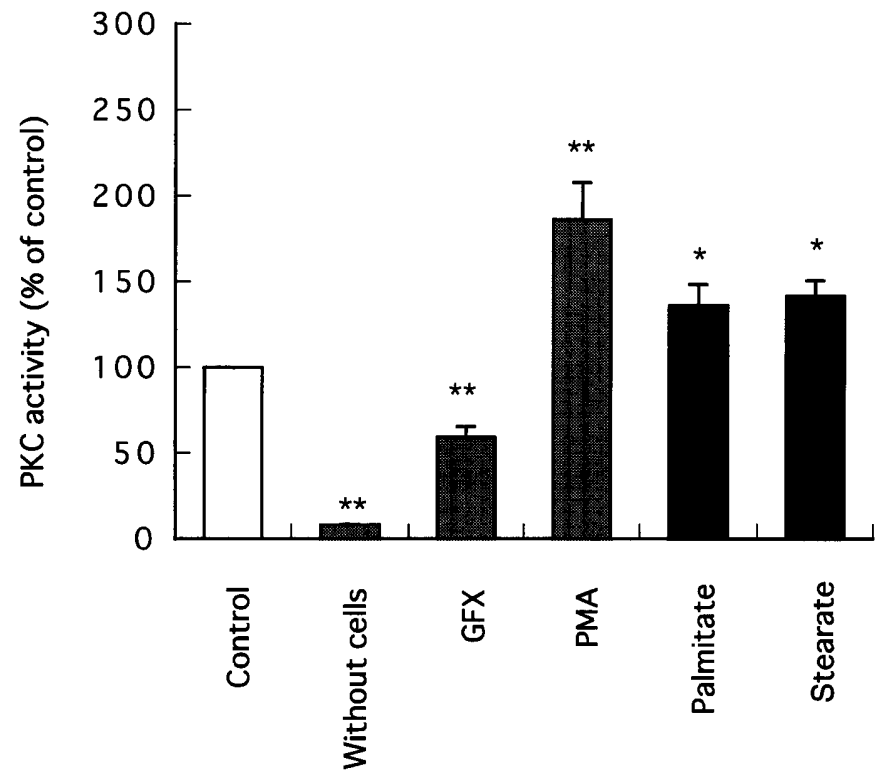

Fig. 4. Effect of saturated non-esterified fatty acids on PKC activity. Confluent cultured aortic smooth muscle cells were exposed to PMA $\left(5 \cdot 10^{-7} \mathrm{~mol} / \mathrm{l}\right)$, GF109203X $\left(5 \cdot 10^{-7} \mathrm{~mol} / \mathrm{l}\right)$, or saturated fatty acids $(200 \mu \mathrm{mol} / \mathrm{l})$. After indicated interval of incubation, PKC activity was measured by in situ assay system as described in Methods. Each experiment was done in triplicate. Results were expressed as a mean percentage of control \pm SEM from 5 independent experiments. $* p<0.05$, $* * p<0.01$ vs. control value

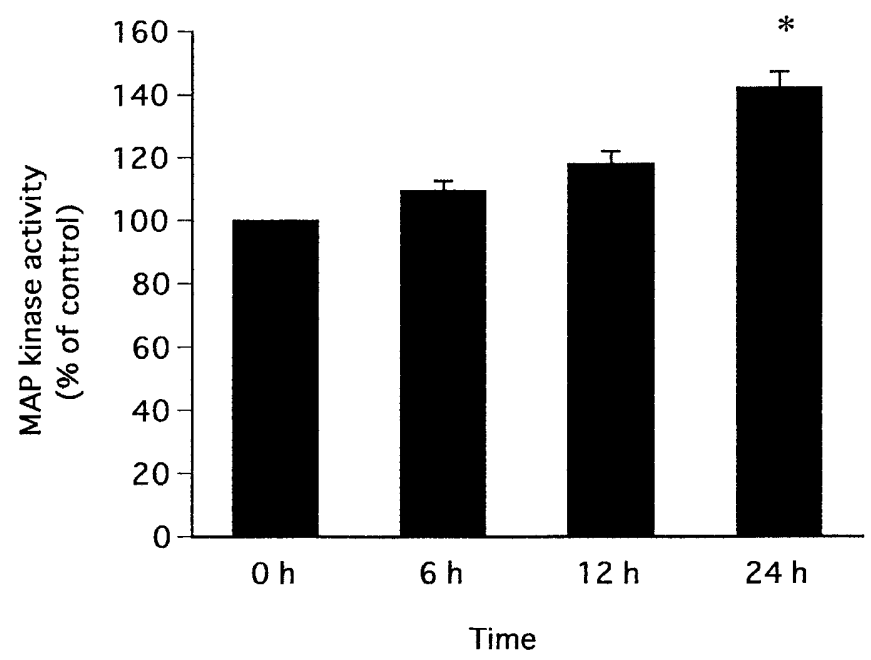

Fig. 5. Time-dependent increase in MAP kinase activity in response to palmitate. Confluent cultured aortic smooth muscle cells were exposed to palmitate $(200 \mu \mathrm{mol} / \mathrm{l})$. After $24 \mathrm{~h}$ incubation, MAP kinase was measured. Results were from 1 experiment with 3 dishes per group. Results were confirmed by 2 separate independent experiments. Results were expressed as mean values \pm SEM normalized by cell number. $* p<0.05$ vs basal value of DAG concentrations

MAP kinase, the effect of GF109203X on the palmitate-induced increase in MAP kinase activity was examined. Exposing the cells to GF109203X $\left(5 \cdot 10^{-7}\right)$ for $2 \mathrm{~h}$ completely restored the palmitate-induced in- 


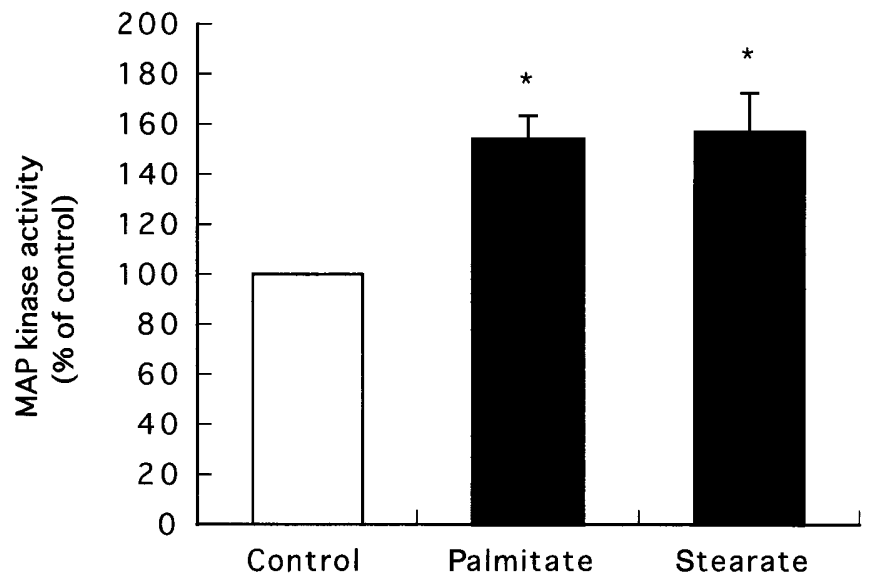

Fig. 6. Effect of saturated non-esterified fatty acids on MAP kinase activity. Confluent cultured aortic smooth muscle cells were exposed to saturated fatty acids $(200 \mu \mathrm{mol} / \mathrm{l})$. After $24-\mathrm{h}$ incubation, MAP kinase was measured. Each experiment was done in triplicate. Results were expressed as a mean percentage of control \pm SEM from 6 independent experiments. $* p<0.05, * * p<0.01$ vs control value
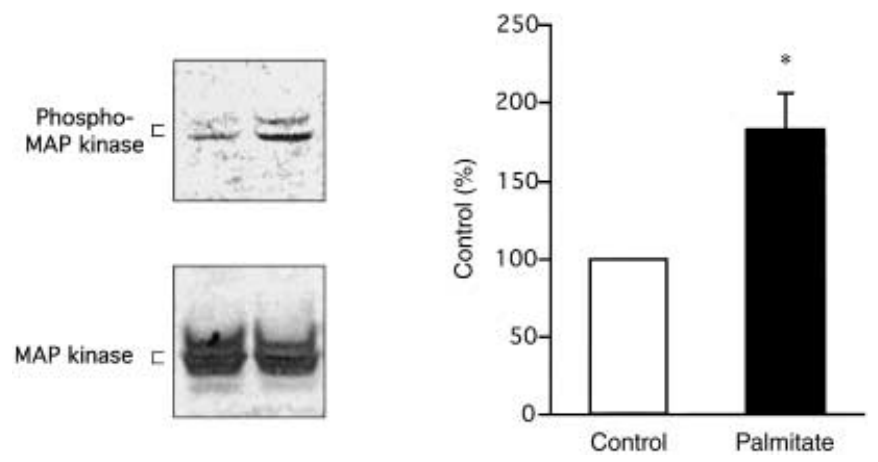

Fig. 7. Effect of palmitate on MAP kinase assessed by western blot analysis. Confluent cultured aortic smooth muscle cells were exposed to palmitate $(200 \mu \mathrm{mol} / \mathrm{l})$. After 24 -h incubation, cells were lysed, subjected to SDS-PAGE and immunoblotted with phospho-specific MAP kinase antibody (left, upper panel). The blots were stripped and reblotted with anti-Erk-1 antibody (left, lower panel). Videodensitometry analysis of the ratio of phospho-MAP kinase to total MAP kinase (right panel). Results were expressed as a mean percentage of control $+\mathrm{SE}$ from 5 independent experiments. $* p<0.01$ vs control value

crease in MAP kinase activity to control concentrations (Fig. 8).

\section{Discussions}

In this study, we clearly showed that the physiological concentrations of long chain saturated NEFAs such as palmitate and stearate increased DAG concentrations in cultured aortic smooth muscle cells. DAG can be formed through multiple pathways. We and other investigators have already shown that increased glucose concentrations stimulate DAG synthesis

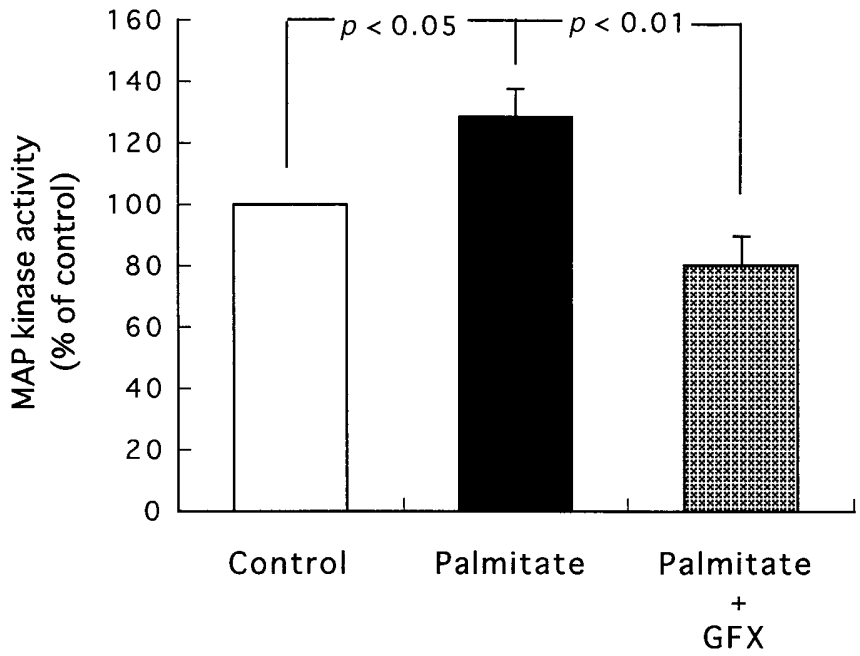

Fig. 8. Effect of PKC inhibitor on palmitate-induced increase in MAP kinase activity. Confluent cultured aortic smooth muscle cells were exposed to palmitate $(200 \mu \mathrm{mol} / \mathrm{l})$ for $24 \mathrm{~h}$. After $2 \mathrm{~h}$ of additional incubation with or without GF109203X $\left(5 \cdot 10^{-7} \mathrm{~mol} / \mathrm{l}\right)$, MAP kinase was measured. Each experiment was done in triplicate. Results were expressed as mean percentage of control \pm SEM from 4 independent experiments

through the de novo pathway from glycolytic intermediates after stepwise acylation, and subsequently stimulate PKC activity in various types of vascular cells and tissues [13-19]. Previous labelling studies showed that ${ }^{3} \mathrm{H}$ palmitate-labelled $\mathrm{DAG}$ pool was significantly increased by high glucose concentrations in cultured aortic endothelial cells, whereas ${ }^{3} \mathrm{H}$ arachidonate-labelled DAG pool was not [15]. Similar findings have been reported in pancreatic islets, where analysis of the fatty acid composition of DAG synthesized through the de novo pathway by high glucose concentrations showed a predominance of palmitate and oleate [36]. These findings are in agreement with the present results that palmitate significantly increased DAG concentrations in cultured aortic smooth muscle cells whereas arachidonate did not. Furthermore, we showed that Triacsin C, which is a potent competitive inhibitor of acyl-CoA synthetase [37, 38], completely restored the increased DAG concentrations induced by palmiate to control concentrations. Triacsin $\mathrm{C}$ has been reported to block de novo synthesis of glycerolipids from glycerol such as DAG and triacylglycerol [39]. The present result strongly supported the notion that saturated NEFA might stimulate DAG synthesis through the de novo pathway. In parallel with DAG changes, saturated NEFA stimulated PKC activity in cultured smooth muscle cells. Because DAG is a physiological PKC activator, it is likely that $\mathrm{PKC}$ activation by saturated NEFAs is mediated by increased DAG. The extent of increases in PKC activities induced by saturated NEFAs appears to be relatively small compared with the increases in DAG concentrations. This could be 
explained by the previous findings that DAG species containing saturated NEFAs are less potent activators than the ones containing unsaturated NEFAs such as 1-stearoyl-2-arachidonoyl DAG [40], which is a most common DAG synthesized by phosphatidylinositol breakdown. It is also possible that these NEFAs might stimulate certain PKC isoenzynes. In other kinds of cells and tissues, similar findings have been reported. One report showed that palmitate stimulated PKC activity probably through the de novo DAG synthesis in pancreatic islets [41]. Recent reports also showed that palmitate induced the immediate-early response genes c-fos and nur-77 through activation of PKC in the pancreatic betacell line INS-1 [42]. In addition, a recent report showed that increases in plasma NEFA as a result of lipid infusion induced the insulin resistance through the activation of PKC in skeletal muscle [43]. These findings might be explained by the same mechanism that we have shown to operate in vascular smooth muscle cells.

Activation of PKC is a key signalling event in vascular smooth muscle cell growth, proliferation and contraction [27-29]. We showed here that saturated NEFAs stimulated MAP kinase activity, which is a common point in the signalling pathway in cell growth [30-32], in parallel with PKC activation in cultured aortic smooth muscle cells. It is known that MAP kinase is regulated not only by PKC-dependent but also by PKC-independent pathway [44]. The present evidence showing that palmitate-induced activation of MAP kinase was restored to control concentrations by GF109203X, a specific inhibitor of PKC, confirmed the PKC-dependent activation of MAP kinase. Other investigations have reported that oleate rapidly induced the PKC-dependent activation of MAP kinase in cultured vascular smooth muscle cells $[45,46]$. This rapid activation (within $30 \mathrm{~min}$ ) of MAP kinase by oleate contrasts with the time course of activation by saturated NEFAs. They also showed that oleate might stimulate PKC activity directly, probably through binding to a site on the regulatory domain distinct from that for DAG or phorbol esters. Oleate might activate PKC through different mechanism from saturated NEFAs.

Previous studies showed that raising plasma NEFA in minipigs with intralipid and heparin increased vascular resistance and raised blood pressure [10]. Other reports have also shown that increased plasma NEFAs in obese hypertensives are extremely resistant to suppression by insulin and correlate with blood pressure $[11,12]$. It is also interesting to note that anti-lipolytic drugs have been reported to normalize an increase in blood pressure as well as hypertriglyceridaemia, and hyperglycaemia in fructose-fed rats which are insulin-resistant animal models [47]. These findings suggest that the increase in plasma NEFAs could be linked with altered vascular func- tions in obesity or insulin resistant state. These results implied that activation of the DAG-PKC pathway induced by saturated NEFAs in vascular smooth muscle cells might be an underlying mechanism for altered vascular functions in obesity or insulin resistant state. One consequence of PKC activation in vascular smooth muscle cells is the activation of MAP kinase, which could be involved in the vascular remodelling and excessive acceleration of atherosclerosis.

In conclusion, saturated NEFAs stimulated de novo DAG synthesis and subsequently activated PKC activity and MAP kinase activity in cultured aortic smooth muscle cells. This could account for altered vascular function and subsequent excessive acceleration of atherosclerosis in patients with the insulin resistance syndrome.

Acknowledgements. This work was supported by a Grant-inAid for Scientific Research (No. 11671126) from the Ministry of Education, Science and Culture, Japan.

\section{References}

1. McGarry JD, Dobbins RL (1999) Fatty acids, lipotoxicity and insulin secretion. Diabetologia 42: 128-138

2. Boden G (1997) Role of fatty acids in the pathogenesis of insulin resistance and NIDDM. Diabetes 46: 3-10

3. Unger R (1995) Lipotoxicity in the pathogenesis of obesitydependent NIDDM. Diabetes 44: 863-870

4. Lee Y, Hirose H, Ohneda M, Johnson JH, McGarry JD, Unger RH (1994) $\beta$-cell lipotoxicity in the pathogenesis of non-insulin-dependent diabetes mellitus of obese rats: impairment in adipocyte- $\beta$-cell relationship. Proc Natl Acad Sci USA 91: 10 878-10 882

5. Mason TM, Goh T, Tchipashvili V et al. (1999) Prolonged increase of plasma non-esterified fatty acids desensitizes the insulin secretory response to glucose in vivo in rats. Diabetes 48: 524-530

6. Warnotte C, Gilon P, Nenquin M, Henquin JC (1994) Mechanism of the stimulation of insulin release by saturated fatty acids. Diabetes 43: 703-711

7. Chen S, Ogawa A, Ohneda M, Unger RH, Foster DW, McGarry JD (1994) More direct evidence for a malonylCoA-carnitine palmitoyltransferase I interaction as a key event in pancreatic $\beta$-cell signalli ng. Diabetes 43: 878-883

8. Crespin SR, Greenough WB, Steiberg D (1973) Stimulation of insulin secretion by long-chain non-esterified fatty acids. J Clin Invest 53: 1979-1984

9. Stein DT, Esser V, Stevenson B et al. (1996) Essentiality of circulating fatty acids for glucose-stimulated insulin secretion in the fasted rat. J Clin Invest 97: 2728-2735

10. Bulow J, Madsen, Hojgaard L (1990) Reversibility of the effects on local circulation of high lipid concentrations in blood. Scand J Clin Lab Invest 50: 291-296

11. Hennes MM, O'Shaughnessy IM, Kelly TM, Labelle P, Egan BM, Kissebah AH (1996) Insulin resistant lipolysis in abdominally-obese hypertensives: Role of the renin-angiotensin system. Hypertension 28: 120-126

12. Egan BM, Hennes MMI, O’Shaughnessy IM, Stepniakowski KT, Kissebah AH, Goodfriend TL (1996) Obesity hypertension is more closely related to impairment of insu- 
lin's fatty acid than glucose lowering action. Hypertension 27 : 723-728

13. King GL, Johnson S, Wu G (1990) Growth Factors in Health and Disease. In: Westermark B, Betscholtz C, Hokfelt B eds, Elsevier Science, Amsterdam, pp 303-317

14. Inoguchi T, Battan R, Handler E, Sportsman JR, Heath W, King GL (1992) Preferential increase of protein kinase C isoform beta II and diacylglycerol concentrationss in the aorta and heart of diabetic rats: differential reversibility to glycemic control by islet cell transplantation. Proc Natl Acad Sci USA 89: 11059-11063

15. Inoguchi T, Xia P, Kunisaki M, Higashi S, Feener EP, King GL (1994) Insulin's effect on protein kinase C and diacylglycerol induced by diabetes and glucose in vascular tissues. Am J Physiol 267: E369-E379

16. Xia P, Inoguchi T, Kem TS, Engerman RL, Oates PJ, King GL (1994) Characterization of the mechanism for the chronic activation of diacylglycerol-protein kinase $\mathrm{C}$ pathway in diabetes and hypergalactosemia. Diabetes 43: 1122-129

17. Craven PA, DeRubertis FR (1989) Protein kinase C is activated in glomeruli from streptozotocin diabetic rats. Possible mediation by glucose. J Clin Invest 83: 1667-1675

18. Wolf BA, Williamson JR, Easom RA, Chang K, Sherman WR Turk J (1991) Diacylglycerol accumulation and microvascular abnormalities induced by elevated glucose concentrationss. J Clin Invest 87: 31-38

19. Shiba T, Inoguchi T, Sportsman JR, Heat WF, Bursell S, King GL (1993) Correlation of diacylglycerol concentrations and protein kinase $\mathrm{C}$ activity in rat retina to retinal circulation. Am J Physiol 265: E783-E793

20. Tesfamariam B, Brown ML, Cohen RA (1991) Elevated glucose impairs endothelium-dependent relaxation by activating protein kinase C. J Clin Invest 87: 1643-1648

21. Studor PK, Craven PA, DeRubertis FR (1993) Role of protein kinase $\mathrm{C}$ in the mediation of increased fibronectin accumulation by mesangial cells grown in high-glucose medium. Diabetes 42: 118-126

22. Ishii H, Jirousek MR, Koya D et al. (1996) Amelioration of vascular dysfunctions in diabetic rats by an oral PKC $\beta$ inhibitor. Science 272: 728-731

23. Haneda M, Araki S, Togawa M (1997) Mitogen-activated protein kinase cascade is activated in glomeruli of diabetic rats and glomerular mesangial cells cultured under high glucose conditions. Diabetes 46: 847-853

24. Koya D, Jirousek MR, Lin Y-W, Ishii H, Kuboki K, King GL (1997) Characterization of protein kinase C $\beta$ isoform activation on the gene expression of transforming growth factor- $\beta$, extracellular matrix components, and prostanoids in the glomeruli of diabetic rats. J Clin Invest 100: 115-126

25. Inoguchi $T$, Ueda F, Umeda F, Yamashita T, Nawata H (1995) Inhibition of intercellular communication via gap junction in cultured aortic endothelial cells by elevated glucose and phorbol ester. Biochem Biophys Res Commun 208: 492-497

26. Kuroki T, Inoguchi T, Umeda F, Ueda F, Nawata H (1998) High glucose induced alteration of gap junction permeability and phosphorylation of connexin-43 in cultured aortic smooth muscle cells. Diabetes 47: 931-936

27. Dzau VJ, Gibbons GH (1991) Endothelium and growth factors in vascular remodeling of hypertension. Hypertension 18 [Suppl III]: III-115-III-121

28. Yong VW (1992) Proliferation of human and mouse astrocytes in vitro: signalling through the protein kinase $\mathrm{C}$ pathway. J Neurol Sci 111: 92-103
29. Rasmussen H, Forder J, Kojima I, Scriabine A (1984) TPAinduced contraction of isolated rabbit vascular smooth muscle. Biochem Biophys Res commun 122: 776-784

30. Jones LG, Ella KM, Bradshaw CD et al. (1994) Activation of mitogen-activated protein kinases and phospholipase D in A7r5 vascular smooth muscle cells. J Biol Chem 269: 23 790-23 799

31. Cobb MH, Boulton TG, Robbins DJ (1991) Extra cellular signal-regulated kinases. Cell Regul 2: 965-978

32. Davis RJ (1993) The mitogen-activated protein kinase signal transduction pathway. J Biol Chem 268: 14 553-14 556

33. Spector AA, Fletcher JE, Ashbrook JD (1971) Analysis of long-chain free fatty acid binding to bovine serum albumin by determination of stepwise equilibrium constants. Biochemistry 10: 3229-3232

34. Blig h EG, Dyer WJ (1959) A rapid method of total lipid extraction and purification. Can J Biochem Physio 37: 911-917

35. Williams B, Schrier R (1992) Characterization of glucoseinduced in situ protein kinase $\mathrm{C}$ activity in cultured vascular smooth muscle cells. Diabetes 41: 1464-1472

36. Wolf BA, Easom RA, Hughes ML, McDaniel ML, Turk J (1989) Secretagogue-induced diacylglycerol accumulation in isolated pancreatic islets: mass spectrometric characterization of the fatty acyl content indicates multiple mechanisms of generation. Biochemistry 28: 4291-4301

37. Tomoda H, Igarashi K, Omura S (1987) Inhibition of acylCoA synthetase by triacsins. Biochim Biophys Acta 921: 595-598

38. Tomoda H, Igarashi K, Cyong JC, Omura S (1991) Evidence for an essential role of long chain acyl-CoA synthetase in animal cell proliferation. J Biol Chem 266: 4214-4219

39. Igal RA, Wang P, Coleman RA (1997) Triacsin C blocks de novo synthesis of glycerolipids and cholesterol esters but not recycling of fatty acid into phospholipid: evidence for functionally separate pools of acyl-CoA. Biochem J 324: 529-534

40. Go M, Sekiguchi K, Nomura H, Kikkawa U, Nishizuka Y (1987) Further studies on the specificity of diacylglycerol for protein kinase $\mathrm{C}$ activation. Biochem Biophys Res Commun 144: 598-605

41. Alcazar O, Qiu-yue Z, Gine E, Tamarit-Rodriguez J (1997) Stimulation of islet protein kinase $\mathrm{C}$ translocation by palmitate requires metabolism of the fatty acid. Diabetes 46: $1153-1158$

42. Roche E, Buteau J, Aniento I, Reig JA, Soria B, Prentoki M (1999) Palmitate and oleate induce the immediate-early response genes c-fos and nur-77 in the pancreatic $\beta$ cell line INS-1. Diabetes 48: 2007-2014

43. Griffin ME, Marcucci MJ, Cline GW et al. (1999) Free fatty acid-induced insulin resistance is associated with activation of protein kinase $\mathrm{C} \theta$ and alterations in the insulin signalling cascade. Diabetes 48: 1270-1274

44. White MF, Kahn CR (1994) The insulin signalling system. J Biol Chem 269: 1-4

45. Gang L, Morinelli TA, Meier KE, Rosenzweig SA, Egan BM (1996) Oleic acid-induced mitogenic signalling in vascular smooth muscle cells: a role for protein kinase C. Circ Res 79: 611-618

46. Gang L, Meier KE, Jaffa AA, Rosenzweig SA, Egan BM (1998) Oleic acid and angiotensin II induce a synergistic mitogenic response in vascular smooth muscle cells. Hypertension 31: 978-985

47. Qu X, Cooney G, Donnelly R (1997) Short term metabolic and haemodynamic effects of GR79236 in normal and fructose-fed rats. Eur J Pharmacol 338: 269-276 